\title{
Studi Tentang Preferensi Konsumen, Sifat Fisiko Kimia dan Nilai Organoleptik Sei Daging Babi asal Kupang (Nusa Tenggara Timur)
}

\author{
Soffy Soetji Widarti ${ }^{1,2}$, Hari Purnomo ${ }^{3}$ dan Djalal Rosyidi ${ }^{3}$ \\ ${ }^{1}$ Mahasiswa Magister Ilmu Ternak Universitas Brawijaya Malang \\ ${ }^{2}$ Dinas Peternakan Provinsi Nusa Tenggara Timur, Jl. Veteran - Kelapa Lima, Kupang, \\ Nusa Tenggara Timur \\ ${ }^{3}$ Fakultas Peternakan Universitas Brawijaya, Jl. Veteran Malang 65145 \\ Email : soffywidarti@yahoo.com
}

\begin{abstract}
ABSTRAK
Sei daging babi asal Kupang (Nusa Tenggara Timur) merupakan salah satu pangan asal daging babi yang diolah secara tradisional dengan menggunakan proses kyuring dan pengasapan. Tujuan penelitian ini adalah untuk melihat preferensi konsumen, sifat fisiko kimia dan nilai organoleptik sei daging babi yang saat ini sangat digemari oleh masyarakat NTT. Penelitian ini dilakukan dengan metode pengamatan dan percobaan menggunakan Rancangan Acak Lengkap (RAL) dengan tiga kali ulangan. Pengamatan dilakukan terhadap empat rumah makan dan konsumen daging sei babi di Kota Kupang. Pengujian sifat fisiko kimia meliputi kadar air, kadar protein, kadar lemak, kadar karbohidrat, dan $\mathrm{pH}$, sedangkan nilai organoleptik yang diuji meliputi warna, tekstur, rasa dan keempukan. Hasil penelitian menunjukkan bahwa tidak ada perbedaan nyata $(\mathrm{p} \geq 0,05)$ diantara sampel daging sei babi keempat rumah makan terhadap kadar air, lemak, karbohidrat, $\mathrm{pH}$, uji tekstur dan keempukan tetapi berbeda pada kadar protein, uji rasa dan warna. Berdasarkan uji indeks efektifitas dapat diambil kesimpulan bahwa sei daging babi dari rumah makan A adalah yang terbaik.
\end{abstract}

Kata kunci : preferensi, fisiko kimia, organoleptik, sei

\section{Study of the Consumer Preference, Physico-Chemical and Organoleptic Properties Pork Sei from Kupang (East Nusa Tenggara)}

\begin{abstract}
Pork sei is a meat product from Kupang (East Nusa Tenggara) that produced traditionally using curing and smoking methods. The purpose of this study was to observe consumer preference, physico-chemical and organoleptic properties of pork sei which is currently very popular in East Nusa Tenggara. The research was carried out by the method of observation and experiment using Completely Randomized Design with three replications. The observations were carried out on four restaurants and pork sei consumer in Kupang. Variables measured were moisture, protein, fat and carbohydrate contents, $\mathrm{pH}$, and organoleptic test including color, texture, taste and tenderness. The results showed that there was no significant difference among pork sei originated from the four selected restaurants on fat content, carbohydrate content, $\mathrm{pH}$, texture and tenderness. However, the protein content, taste and color were different significantly $(P<0.05)$. Based on the effectivity index analysis, it can be concluded that the best samples was originated from restaurant $A$.
\end{abstract}

Key words : preference, physico-chemical, organoleptic, sei 


\section{PENDAHULUAN}

Produk pangan asal daging sangat beragam dan banyak ditemukan di hampir tiap daerah di Indonesia. Salah satu produk daging unggulan daerah Nusa Tenggara Timur adalah sei. Sei adalah produk daging asap dengan potongan panjang yang dibuat melalui proses sederhana dengan memadukan proses kyuring dan pengasapan. Perpaduan kedua proses ini akan menghasilkan suatu produk daging dengan citarasa khas (Rubino, 1998). Citarasa yang khas dihasilkan dari kayu kusambi (Schleichere olease) sebagai bahan pengasap dan daun kusambi yang dipakai untuk menutup daging selama proses pengasapan (Malelak et al., 2009).

Sei dapat dibuat dari daging sapi, daging babi atau daging rusa bahkan saat ini juga sudah diproduksi sei daging ikan. Sei yang berasal dari daging babi sangat digemari oleh masyarakat Nusa Tenggara Timur pada beberapa tahun belakangan ini. Hal ini mendorong semakin banyaknya rumah makan sei daging babi yang berkembang di Kota Kupang. Saat ini ada kurang lebih 15 rumah makan di Kota Kupang yang menyediakan masakan sei daging babi dengan produksi perhari berkisar antara $10-80$ kilogram. Masingmasing rumah makan mempunyai resep berbeda dalam cara mengolah sei daging babi meskipun dasar pengolahannya sama yaitu melalui kyuring dan pengasapan.

Penelitian tentang sei daging babi masih terbatas, sedangkan penelitian sei daging sapi sudah banyak dilakukan pada sifat fisik, kimia, organoleptik, dan cemaran mikroba dengan berbagai perlakuan. Berbagai macam kualitas sei daging sapi dapat dilihat dari penelitian-penelitian tentang penggunaan berbagai konsentrasi garam, suhu dan lama pengasapan (Poma dan Mandala, 1995), penggunaan konstruksi rumah asap (Sogen et al., 1995), penggunaan berbagai bahan dan waktu kyuring (Rubino, 1998), pemeraman daging dengan getah pepaya (Adu, 2001), keamanan pangan (Badewi, 2002), tingkat pencemaran mikroba dan faktor-faktor yang mempengaruhi (Adu, 2005), penggunaan berbagai jenis kayu bakar (Nuban, 2006), cuka apel (Pengge, 2008) dan asap cair (Malelak et al., 2009). Oleh karena itu dipandang perlu untuk melakukan pengamatan dan penelitian tentang sei daging babi sebagai salah satu produk pangan asal hewan yang aman, sehat dan bernilai gizi baik.

\section{MATERI DAN METODE}

Materi dalam penelitian ini adalah sei yang berasal dari daging babi yang diolah dengan proses kyuring dan pengasapan yang diambil dari empat rumah makan di Kota Kupang. Bahan-bahan yang digunakan adalah : (1) lembaran kuisioner dan (2) sei daging babi yang dibeli dari 4 (empat) rumah makan di Kupang masing-masing sebanyak 3000 gram untuk tiga kali ulangan.

Metode yang digunakan dalam penelitian ini adalah pengamatan (observasi) dan percobaan (Singarimbun dan Effendi, 1989). Pengamatan dilakukan dengan cara wawancara terhadap sepuluh pemilik rumah makan sei daging babi di Kota Kupang dan pengisian lembar kuisioner oleh 50 orang penikmat sei daging sapi dan babi di Kota Kupang (preferensi konsumen). Hasil wawancara dan kuisioner menentukan empat rumah makan sei daging babi yang dibandingkan melalui uji organoleptik dan analisis proksimat. Uji organoleptik dilakukan oleh 30 pegawai pada Dinas Peternakan Provinsi Nusa Tenggara Timur. Pengujian sifat fisiko-kimia dilakukan di Laboratorium Kimia Pakan Fakultas Peternakan Universitas Nusa Cendana Kupang. Hasil uji organoleptik dan analisis proksimat dari keempat rumah makan akan dianalisis menggunakan analisis ragam.

Proses penelitian diawali dengan pengamatan pada rumah makan sei daging babi dan pengisian kuisiner oleh konsumen sei daging babi yang ada di Kota Kupang. Dari hasil wawancara terhadap pemilik rumah makan dan rujukan dari konsumen sei daging babi, maka ditentukan empat rumah 
makan yang memenuhi kriteria untuk diambil sampel sebagai bahan penelitian. Sei daging babi dari empat rumah makan di Kota Kupang masing-masing sebanyak 1000 gram dibeli sebanyak tiga kali yang dianggap sebagai ulangan. Rancangan penelitian yang dipakai adalah Rancangan Acak Lengkap dan jika ada perbedaan dilanjutkan dengan uji Beda Nyata Terkecil (Kusriningrum, 2010).

Parameter yang diamati adalah komposisi gizi sei daging babi yang meliputi kadar air (metode oven), protein (metode Kjeldahl), lemak (metode Soxlet) dan karbohidrat (berdasarkan berat kering dan bahan organik) (Andarwulan et al., 2011). Selanjutnya dilakukan uji fisik untuk mengetahui keasaman dengan $\mathrm{pH}$-meter (Anonim, 2004). Uji organoleptik dilakukan dengan hedonic test menurut Setyaningsih et al. (2010) dengan jumlah panelis konsumen sebanyak minimal 30 orang. Setiap panelis akan memilih komponen palatabitas mana yang paling disukai antara empat macam sei daging babi dengan cara mengisi lembar penilaian yang telah disediakan.

\section{HASIL DAN PEMBAHASAN}

\section{Observasi (Pengamatan)}

Hasil wawancara terhadap sepuluh pemilik rumah makan sei daging babi di Kota Kupang menunjukkan bahwa mereka memulai usaha rumah makan antara tahun 2006 sampai sekarang. Jumlah babi yang dipotong antara satu sampai tiga ekor perhari dengan produksi sei sekitar $10-80 \mathrm{~kg}$, kecuali pada saat hari raya keagamaan jumlah babi yang dipotong bisa mencapai 10 ekor per hari. Sei daging babi pada lima rumah makan setiap harinya selalu habis terjual, sedangkan pada lima rumah makan lainnya tidak habis terjual dan disimpan dalam lemari pendingin untuk keesokan harinya dipanaskan kembali. Jenis babi yang dipakai untuk produksi sei adalah jenis durox atau hybrid berumur 3 - 4 bulan yang diperoleh dari pengusaha babi setempat tetapi ada juga yang menggunakan babi lokal jika babi jenis durock dan hybrid tidak tersedia.

Bahan tambahan yang biasa digunakan dalam proses kyuring adalah garam, bumbu-bumbu (lada, ketumbar, jintan, asam, bawang putih, jahe dan serai), pewarna kesumba dan penyedap, tetapi ada yang hanya menggunakan garam sebagai bahan utama kyuring dengan penambahan darah segar untuk memberi warna sehingga tampak lebih menarik. Ada satu rumah makan yang menambahkan madu timor untuk memberi warna lebih mengkilat dan menambah keempukan. Proses kyuring biasanya dilakukan selama $10-15$ menit dengan alasan permintaan konsumen tinggi, sehingga tidak memungkinkan untuk melakukan proses kyuring terlalu lama.

Kayu yang digunakan untuk proses pengasapan adalah kayu kusambi dengan alasan bara bagus dan asap tidak berbau. Jarak bara kayu dengan para-para tempat meletakkan daging sekitar $50-100$ centimeter. Para-para dibuat dari besi tetapi ada yang menggunakan kayu pohon jambu biji dengan alasan daging akan lebih masak sempurna. Lama proses pengasapan sekitar 15 - 45 menit dan bila segera dikonsumsi akan dimatangkan lagi dengan menggunakan bara api yang jaraknya hanya 10 centimeter dari daging. Daun kusambi dipakai sebagai penutup sei dengan alasan penampakan akan lebih bagus (memberi warna merah) dan panas yang keluar akibat pengasapan akan ditahan oleh daun, sehingga kembali masuk dalam daging dan mematangkan daging dengan sempurna. Daun kusambi tidak selalu dipakai dengan alasan berdebu dan terdapat sarang laba-laba selain juga ketersediaannya tidak selalu ada.

Proses pembuatan sei daging babi adalah babi dipotong, digantung untuk dipotong memanjang, dicampur dengan bumbu-bumbu dan didiamkan selama 10 15 menit, diletakkan di atas para-para, ditutup dengan daun kusambi, dilakukan pengasapan dengan menggunakan kayu kusambi, dimatangkan bila akan dikonsumsi langsung, dan dilakukan pengemasan bila tidak dikonsumsi langsung. 
Sebanyak 50 konsumen sei daging babi di Kota Kupang yang terdiri dari 18 orang pria dan 34 orang wanita menunjukkan bahwa sei daging babi digemari karena citarasanya sangat enak (50\%) dan enak (50\%). Sebanyak 46\% konsumen telah mengkonsumsi sei daging babi selama lebih dari satu tahun. Dalam satu bulan sebanyak $52 \%$ konsumen mengkonsumsi sei daging babi dua kali dan sekali konsumsi sebanyak 100 - 200 gram. Keamanan, kemasan, nama produk dan kesegaran sei daging babi menjadi perhatian bagi sebagian besar konsumen (40\%-70\%).

Efek kesehatan menjadi bagian yang penting menyangkut kandungan lemak sei daging babi yang memberi nilai ketidaksukaan sebanyak $45 \%$ sehingga setuju jika lemak dikurangi $\quad(78 \%$ konsumen), lemak dihilangkan (68\% konsumen) dan lemak diganti dengan komponen yang lebih menyehatkan $(50 \%$ konsumen). Modifikasi sei daging babi dianggap tidak perlu oleh $74 \%$ konsumen. Sebanyak $82 \%$ konsumen setuju jika sei daging babi harus memenuhi syarat ASUH (aman, sehat, utuh dan higienis).

Sebanyak 50\%-70\% mengkonsumsi sei daging babi bukan merupakan gaya hidup, kebiasaan, gengsi, eksklusif, terpandang dan karena pergaulan. Menurut $72 \%$ konsumen sei daging babi dikonsumsi oleh konsumen tertentu dan diproduksi secara terbatas (64\%). Kesehatan, sifat fisiko-kimia dan harga menjadi faktor yang berpengaruh terhadap pembelian sei daging babi (50\% - 70\% konsumen).

Hasil wawancara dengan sepuluh pemilik rumah makan sei daging babi di Kota Kupang dan pengisian lembar kuisoner konsumen sei daging babi ditetapkan empat rumah makan terbaik sebagai sampel untuk uji organoleptik dan melihat sifat fisiko kimia sei daging babi.

\section{Eksperimen (Percobaan)}

\section{Kadar Air}

Data dalam Tabel 1 menunjukkan hasil analisis ragam kadar air sampel sei daging babi dari keempat rumah makan yang tidak berbeda nyata $(\mathrm{P}>0,05)$. Tidak adanya perbedaan secara nyata kadar air keempat sampel sei, karena waktu yang diperlukan untuk proses pengasapan hampir sama yaitu sekitar 10 sampai 15 menit. Menurut Badewi (2002) suhu dan lama pengasapan memiliki peranan penting dalam penurunan kadar air produk. Semakin lama dan tinggi suhu pengasapan, penurunan kadar air semakin cepat, sehingga kadar air akan semakin rendah. Setelah dilakukan pengasapan maka kadar air sampel sei dari keempat rumah makan mengalami penurunan tetapi tidak ada perbedaan diantaranya.

Proses penggaraman (kyuring) juga mempengaruhi kadar air dalam daging dimana natrium klorida yang bersifat higroskopis menyebabkan air bebas yang terdapat dalam interstisial sel daging tertarik keluar, sehingga jumlah air dalam daging berkurang (Rubino, 1998). Jumlah garam yang diberikan pada proses kyuring keempat sampel sei berkisar antara $0,5-1 \%$ dari berat daging, sehingga menghasilkan produk sei daging babi dengan kadar air yang tidak berbeda.

Nuban (2006) dalam kesimpulan penelitiannya menyatakan bahwa penggunaan berbagai jenis kayu bakar pada proses pembuatan sei daging sapi akan menghasilkan kadar air yang berbeda. Keempat rumah makan menggunakan kayu kusambi sebagai bahan bakar proses pembuatan sei sehingga menghasilkan kadar air yang tidak berbeda.

\section{Kadar Protein}

Data dalam Tabel 1 menunjukkan hasil analisis ragam kadar protein kasar sei daging babi berdasarkan berat kering dari empat rumah makan di Kota Kupang yang berbeda nyata $(\mathrm{P}<0,05)$. Proses pengasapan yang dilakukan pada rumah makan $D$ menggunakan para-para dari kayu pohon jambu biji, sedangkan rumah makan yang lainnya menggunakan para-para dari besi. Hal ini menyebabkan kadar protein sampel sei daging babi dari rumah makan $\mathrm{D}$ lebih tinggi dari rumah makan lainnya. Ada 
Tabel 1. Rata-rata kadar air, protein, lemak, karbohidrat dan $\mathrm{pH}$ sampel sei daging babi keempat rumah makan

\begin{tabular}{cccccc}
\hline $\begin{array}{c}\text { Rumah } \\
\text { makan }\end{array}$ & Kadar air (\%) & $\begin{array}{c}\text { Kadar protein } \\
(\%)\end{array}$ & $\begin{array}{c}\text { Kadar lemak } \\
(\%)\end{array}$ & $\begin{array}{c}\text { Kadar } \\
\text { karbohidrat }(\%)\end{array}$ & Nilai pH \\
\hline A & $49,4 \pm 2,46$ & $51,57 \pm 3,05^{\mathrm{b}}$ & $26,40 \pm 1,26$ & $14,5 \pm 3,53$ & $5,787 \pm 0,11$ \\
B & $53,8 \pm 8,29$ & $44,20 \pm 3,81^{\text {a }}$ & $27,62 \pm 2,11$ & $22,1 \pm 1,86$ & $5,735 \pm 0,08$ \\
C & $50,9 \pm 4,93$ & $50,79 \pm 3,47^{\mathrm{b}}$ & $27,87 \pm 1,88$ & $13,8 \pm 2,93$ & $5,780 \pm 0,08$ \\
D & $52,5 \pm 8,59$ & $51,83 \pm 2,68^{\mathrm{b}}$ & $28,49 \pm 0,42$ & $14,5 \pm 5,13$ & $5,777 \pm 0,09$ \\
\hline
\end{tabular}

$\overline{\mathrm{a}, \mathrm{b}}$ superskrip yang tidak sama dalam satu kolom menunjukkan ada perbedaan nyata di antara perlakuan $(\mathrm{P}<0,05)$.

para-para dari besi menyebabkan kerusakan sejumlah protein sehingga menyebabkan kandungan proteinnya lebih rendah daripada para-para yang dibuat dari kayu.

\section{Kadar Lemak}

Data dalam Tabel 1 menunjukkan hasil analisis ragam kadar lemak kasar sampel sei daging babi berdasarkan berat kering dari empat rumah makan di Kota Kupang yang tidak berbeda nyata $(\mathrm{P}>0,05)$. Wawancara dengan pemilik empat rumah makan sei menyatakan bahwa babi yang biasa dipotong adalah babi durock umur $3-4$ bulan dengan berat hidup lebih kurang 100 kilogram dan diambil seluruh bagian karkas termasuk lemak intermuskuler dan intramuskuler. Bahan tambahan dalam proses kyuring dan pengasapan yang dilakukan keempat rumah makan hampir sama, sehingga kadar lemak juga menunjukkan hasil tidak berbeda nyata.

\section{Kadar Karbohidrat}

Data dalam Tabel 1 menunjukkan hasil analisis ragam kadar karbohidrat sampel sei daging babi berdasarkan berat kering dari empat rumah makan di Kota Kupang yang tidak berbeda nyata $(\mathrm{P}>0,05)$. Perlakuan dan bahan yang ditambahkan dalam proses pembuatan sei pada keempat rumah makan hampir sama, sehingga kadar karbohidrat tidak berbeda. Menurut Rubino (1998) kadar karbohidrat pada sei daging sapi dapat berbeda apabila dalam proses pembuatannya ditambahkan gula lontar sebagai peningkat komposisi gizi umumnya dan karbohidrat pada khususnya. Garam yang ditambahkan pada proses pembuatan sei menyebabkan kadar karbohidrat sei menurun, karena garam bersifat higroskopis sehingga menarik sejumlah glikogen terlarut dalam daging keluar.

\section{Keasaman (pH)}

Data dalam Tabel 1 menunjukkan hasil analisis ragam nilai $\mathrm{pH}$ sampel sei daging babi dari empat rumah makan di Kota Kupang yang tidak berbeda nyata $(\mathrm{P}>0,05)$. Berdasarkan wawancara terhadap pemilik keempat rumah makan, maka seluruh proses pembuatan sei daging babi yang dilakukan adalah hampir sama sehingga kemungkinan $\mathrm{pH}$ yang didapat juga tidak berbeda. Badewi (2002) mendapatkan $\mathrm{pH}$ sei daging sapi yang bervariasi dan berbeda, karena berbagai macam perlakuan yang meliputi perbedaan lama kyuring, kayu bakar, lama pengasapan dan lama penyimpanan.

\section{Uji Organoleptik Warna}

Data dalam Tabel 2 menunjukkan nilai kesukaan panelis terhadap warna sampel sei daging babi dari empat rumah makan di Kota Kupang yang berbeda sangat nyata $(\mathrm{P}<0,01)$. Warna sei daging babi dari rumah makan A menunjukkan nilai kesukaan tertinggi yang tidak berbeda nyata dengan rumah makan $\mathrm{D}$ dan $\mathrm{C}$ tetapi berbeda dengan rumah makan B.

Warna sei daging babi dari rumah makan A lebih disukai panelis, karena pada proses kyuring digunakan $\mathrm{NaCl}$ dan darah segar babi serta pada proses pengasapan ditutup dengan daun kusambi. Rumah makan B, C dan D hanya menggunakan $\mathrm{NaCl}$ pada proses kyuring meskipun 
Tabel 2. Rata-rata penilaian panelis terhadap uji organoleptik warna, tekstur, rasa dan keempukan sampel sei daging babi keempat rumah makan

\begin{tabular}{ccccc}
\hline $\begin{array}{c}\text { Rumah } \\
\text { makan }\end{array}$ & $\begin{array}{c}\text { Rata-rata nilai uji } \\
\text { warna }\end{array}$ & $\begin{array}{c}\text { Rata-rata nilai uji } \\
\text { tekstur }\end{array}$ & $\begin{array}{c}\text { Rata-rata nilai uji } \\
\text { rasa }\end{array}$ & $\begin{array}{c}\text { Rata-rata nilai uji } \\
\text { keempukan }\end{array}$ \\
\hline A & $5,722 \pm 0,12^{\mathrm{b}}$ & $5,800 \pm 0,27$ & $6,056 \pm 0,17^{\mathrm{b}}$ & $5,700 \pm 0,27$ \\
$\mathrm{C}$ & $5,200 \pm 0,17^{\mathrm{b}}$ & $5,322 \pm 0,42$ & $5,644 \pm 0,25^{\mathrm{b}}$ & $5,367 \pm 0,36$ \\
$\mathrm{D}$ & $5,233 \pm 0,35^{\mathrm{b}}$ & $5,444 \pm 0,19$ & $5,478 \pm 0,44^{\mathrm{b}}$ & $5,278 \pm 0,37$ \\
B & $4,533 \pm 0,05^{\mathrm{a}}$ & $5,233 \pm 0,28$ & $5,217 \pm 0,44^{\mathrm{a}}$ & $5,333 \pm 0,05$ \\
\hline a,b & \multicolumn{4}{l}{} \\
perlakerskrip yang tidak sama dalam $(\mathrm{P}<0,01)$.
\end{tabular}

dilakukan penutupan daging dengan daun kusambi pada proses pengasapan.

Warna merah darah berasal dari hemoglobin yang unsur pembuatnya adalah zat besi. Hemoglobin tersusun dari protein, globin dan zat warna (heme) (Soeparno, 2005). Pada proses daging babi yang dicampur $\mathrm{NaCl}$ dan darah diduga terjadi reaksi-reaksi kimia pigmen heme, sehingga menghasilkan warna daging kyured yang diinginkan. Hal ini menyebabkan penampakan warna sei daging babi dari rumah makan A lebih disukai oleh panelis.

\section{Uji Organoleptik Tekstur}

Data dalam Tabel 2 menunjukkan hasil analisis ragam nilai kesukaan panelis terhadap tekstur sampel sei daging babi dari empat rumah makan di Kota Kupang yang tidak berbeda nyata $(\mathrm{P}>0,05)$. Sei daging babi dari keempat rumah makan berasal dari bangsa, umur dan berat badan yang hampir sama dan mengalami pengolahan dengan bahan tambahan dan cara yang hampir sama pula, sehingga menghasilkan tekstur sei daging babi yang tidak berbeda.

\section{Uji Organoleptik Rasa}

Data dalam Tabel 2 menunjukkan hasil analisis ragam nilai kesukaan panelis terhadap rasa sampel sei daging babi dari empat rumah makan di Kota Kupang yang berbeda nyata $(\mathrm{P}>0,05)$. Rasa sei daging babi dari rumah makan $\mathrm{A}$ menempati nilai tertinggi, tidak berbeda dengan rumah makan $\mathrm{C}$ dan $\mathrm{D}$ tetapi berbeda dengan rumah makan $\mathrm{B}$. Hal ini diduga karena pengaruh penambahan darah pada proses kyuring, sehingga menimbulkan rasa yang lebih disukai konsumen. Interaksi antara darah segar dan $\mathrm{NaCl}$ pada proses kyuring dan komponen asap menciptakan rasa daging yang sedikit lebih disukai oleh panelis.

\section{Uji Organoleptik Keempukan}

Data dalam Tabel 2 menunjukkan hasil analisis ragam nilai kesukaan panelis terhadap keempukan sampel sei daging babi dari empat rumah makan di Kota Kupang yang tidak berbeda nyata $(\mathrm{P}>0,05)$. Keseluruhan proses pembuatan sei daging babi yang dilakukan oleh keempat rumah makan di Kota Kupang menghasilkan tingkat keempukan daging asap yang hampir sama disukai oleh panelis. Hal ini dikarenakan daging babi yang digunakan pada proses pembuatan sei pada keempat rumah makan berasal dari bangsa, spesies dan umur yang sama.

\section{KESIMPULAN}

Kualitas fisik, kimia dan organoleptik sei daging babi tradisional dari keempat rumah makan menunjukkan hasil yang tidak berbeda nyata kecuali kadar protein, nilai kesukaan panelis terhadap organoleptik warna dan rasa. Panelis lebih menyukai warna dan rasa sei daging babi dari rumah makan A karena dalam proses kyuring dicampur dengan darah. Hasil analisis indeks efektifitas menyatakan bahwa hasil terbaik adalah sei daging babi asal rumah makan A. 


\section{DAFTAR PUSTAKA}

Adu, A.A., 2001. Keempukan Daging Sei Sapi Bali yang Diberi dan Diperam dengan Getah Pepaya, Skripsi, Universitas Nusa Cendana, Kupang.

Adu, A.A., 2005. Perbedaan Tingkat Pencemaran Mikroba pada Proses Pengolahan Daging Sei Sapi antara Perusahaan Pengolahan Daging Sapi Modern dan Tradisional di Kota Kupang, Tesis, Universitas Airlangga, Surabaya.

Andarwulan, N., F. Kusnandar, D. Herawati, 2011. Analisis Pangan. Cetakan Pertama. PT. Dian Rakyat. Jakarta.

Anonim, 2004. Uji pH dengan pH meter. SNI 06-6989.11-2004. All About Sanitarian : www.blogger.com. Diposkan oleh Munif Arifin. Diakses pada 8/11/2011

Badewi, B, 2002. Studi Teknologi dan Mutu serta Keamanan Pangan Daging Asap (Sei) di Kecamatan Kupang Barat Nusa Tenggara Timur, Program Pasca Sarjana, Institut Pertanian Bogor. Bogor.

Kusriningrum, R.S., 2010. Perancangan Percobaan. Cet. Ke-2. Pusat Penerbitan dan Percetakan Unair (AUP). Surabaya.

Malelak, G.E.M, G.M. Sipahelut, D.K. Hau, dan D.T. Laylogo, 2009. Pengaruh Penggunaan Asap Cair Terhadap Karakteristik Daging Sei. Laporan Hasil Kegiatan Universitas Cendana dan Badan Penelitian danPengembangan Pertanian Kupang. Kupang. Nusa Tenggara Timur.

Nuban, N.F.P., 2006. Pengaruh Penggunaan Berbagai Jenis Kayu Bakar sebagai Bahan
Pengasap terhadap Kandungan Nutrisi Daging Sei (Daging Asap Khas Timor), Skripsi, Jurusan Produksi Ternak, Fakultas Peternakan, Universitas Nusa Cendana, Kupang.

Pengge, R.L, 2008. Pengaruh Pemberian Berbagai Level Cuka Apel (Malus sylvestris mill) dan Lama Simpan Terhadap Kualitas Daging Sei, Tesis, Universitas Nusa Cendana, Kupang.

Poma, H. dan Y. Mandala, 1995. Pengaruh Berbagai Konsentrasi Garam dan Suhu serta Lama Pengasapan Terhadap Kualitas Daging Sei, Laporan Proyek Lapang, Universitas Nusa Cendana, Kupang.

Sogen, A.S., C.A. Gaina, dan F.A. Bue, 1995. Pengaruh Konstruksi Rumah Asap Terhadap Mutu Daging Sapi Asap, Proyek Lapang, Jurusan Manajemen Pertanian Lahan Kering, Politeknik Pertanian, Universitas Nusa Cendana. Kupang

Rubino, 1998. Efek Curing pada Pembuatan Daging Sei terhadap Aseptabilitas, Komposisi Gizi, Masa Simpan dan Residu Nitrit, Tesis, Program Pasca Sarjana, Universitas Gadjah Mada, Yogyakarta.

Setyaningsih, D., A. Apriyantono, dan M.P. Sari, 2010. Analisis Sensori untuk Industri Pangan dan Agro, IPB Press, Kampus IPB Taman Kencono Bogor.

Soeparno, 2005. Ilmu dan Teknologi Daging, Gadjah Mada University Press, P.O. Box 14, Bulaksumur, Yogyakarta

Singarimbun, M. dan S. Effendi, 2008. Metode Penelitian Survei. Cetakan kesembilanbelas. LP3ES. Jakarta. 